\title{
Developing DNA Markers for a Wild Source of Resistance to Papaya Ringspot Virus
}

C. Kanchana-udomkan, M.R. Razean and R. Drew

School of Biomolecular and Physical Sciences

Griffith University

Nathan, Queensland

Australia

\author{
C. Peace \\ Department of Horticulture \\ Washington State University \\ Pullman, Washington State \\ USA
}

Keywords: disease resistance genes, nucleotide binding sites, introgression breeding, Carica papaya, Vasconcellea

\begin{abstract}
Production of papaya (Carica papaya) is limited throughout its growing regions by the devastating disease of Papaya Ringspot Virus type P(PRSV-P). Papaya breeding programmes for PRSV-P resistance target two sources of resistance from crop wild relatives. The resistance loci from $V$. pubescens were identified in a segregating population resulting from an interspecific cross between $V$. pubescens and $V$. parviflora. The resistance loci in $V$. pubescens were located on supercontig (SC) 28 of the papaya whole genome sequence although SC28 is not yet anchored to any linkage group (LG). Recent investigations indicate that SC28 could be located at the end of LG5. Another species $V$. quercifolia also carries PRSV-P resistance, although more quantitative in action, and this species produces some fertile hybrids when crossed to $C$. papaya. The aim of this study was to target polymorphism at the end of LG5 and on SC28 in C. papaya and $V$. quercifolia. Five candidate resistant genes were used, corresponding to three nucleotide binding sites (NBS; NBS9.305, NBS9.308 and NBS18.235) at the end of LG5 and one NBS (NBS28.12) and one kinase gene (STK105) on SC28. Primers were designed for each gene and used to amplify DNA of papaya variety '2.001' and an accession of $V$. quercifolia. Resultant DNA sequences were aligned by BLASTN to the papaya whole genome sequence, indicating $98-100 \%$ and $89-99 \%$ identities for the '2.001' and $V$. quercifolia amplicons, respectively, and 82-93\% identity between these two species.
\end{abstract}

\section{INTRODUCTION}

Papaya Ringspot Virus type P (PRSV-P) has been the most destructive disease of papaya production worldwide. To date, no resistance to the virus has been found in Carica papaya. The methods to control the disease include transgenic plants and conventional breeding to develop virus resistant genotypes. However, the use of transgenic plants in many countries is limited to specific strains of virus (Tennant et al., 1994). Development of resistant varieties is likely to be a long term method to prevent and control the disease for papaya production.

Natural sources of resistance to PRSV-P have been found in crop wild relatives. Two sources of resistance, from Vasconcellea pubescens and V. quercifolia, have been used in papaya breeding programs for PRSV-P resistance. The former species, $V$. pubescens, is immune to PRSV-P (Badillo, 1993, 2001), however, it does not produce fertile hybrids when crossed with papaya (Drew et al., 1998). Thus, V. parviflora was introduced to the breeding programme as a bridging species to introgress resistance genes to papaya (Drew et al., 1998) and to study resistant genes controlling PRSV-P in V. pubescens (Dillon et al., 2005, 2006).

DNA markers linked to PRSV-P resistance alleles were identified in progeny of an interspecific cross between $V$. pubescens $\times V$. parviflora. One of the markers, Opa11_5r, revealed $100 \%$ linkage to the prsv-1 locus controlling PRSV-P resistance in $V$. pubescens. DNA sequence analysis of the marker showed similarity to a protein kinase gene (Dillon et al., 2006). One year later, the papaya genome was successfully sequenced, analysed and published by Chen et al. (2007). The sequences of alleles linked to prsv-l locus have been 
investigated further and found to be located on supercontig (SC) 28, which has not yet been located on any linkage group (LG) of the papaya genetic map (J. Zhu, pers. commun.). Another two kinase genes and a nucleotide binding site (NBS) gene on SC28 which could be related to PRSV-P resistance have been discovered recently (M.R. Razean, pers. commun.).

Unlike $V$. pubescens, $V$. quercifolia can produce fertile hybrids when crossed to C. papaya (Drew et al., 1998) thus allowing transferability of the resistance alleles to papaya. Therefore, a papaya breeding program to develop PRSV-P resistant genotypes has been developed using this source of resistance and backcross populations have been achieved (Drew et al., 2006). This research aimed to develop DNA markers linked to PRSV$P$ resistance genes in $V$. quercifolia based on information on resistance alleles controlling PRSV-P resistance in $V$. pubescens. However, to date there is no solid evidence showing the location of the alleles controlling PRSV-P resistance in $V$. pubescens on the papaya genetic map. Therefore, this study also aimed to reveal the location of alleles specific to prsv-1 on the published papaya genetic map using sequences of DNA markers linked to PRSV-P resistance. These markers/genes will assist the selection of genotypes carrying PRSV-P resistance genes in papaya breeding programs in the future.

\section{MATERIALS AND METHODS}

The sequences of DNA markers linked to PRSV-P resistance which were identified in $V$. pubescens were obtained from Dillon et al. (2006) and BLASTed to the papaya genome database on NCBI. The results showed sequence similarity to genes at the end of LG5 of the papaya genome, therefore, another three NBS genes (NBS9.305, NBS9.308 and NBS18.235) located near the end of LG5 (Porter et al., 2009) were also included in this study. DNA primers were designed from information of papaya DNA sequences from Razean (pers. commun.) and Porter et al. (2009) using Primer3 software (Untergrasser et al., 2012) with default setting at GC content more than $40 \%$.

Genomic DNAs were extracted from C. papaya var. 2.001 and Vasconcellea quercifolia using CTAB method (Delaporta et al., 1983) with minor modification. Quantity and quality of DNA were assessed by a NanoDrop spectrophotometer (Thermoscientific). The DNA samples were amplified using primer pairs in the reaction of 1X MyTaq PCR buffer ( $1 \mathrm{mM}$ dNTPs, $3 \mathrm{mM} \mathrm{MgCl} 2$, stabilizers and enhancers; Bioline), 0.15 unit MyTaq DNA polymerase (Bioline), $0.45 \mu \mathrm{M}$ each of forward and reverse primer, $50 \mathrm{ng}$ genomic DNA in a final volume of $15 \mu \mathrm{L}$. The PCR reactions were performed in a thermal cycler (BioRad) with the cycler of $95^{\circ} \mathrm{C} 1 \mathrm{~min} ; 35$ cycles of $95^{\circ} \mathrm{C} 1 \mathrm{~min}$, annealing temperatures were optimized between $45-60^{\circ} \mathrm{C}$ for $1 \mathrm{~min}$ and $2 \mathrm{mins}$ of $72^{\circ} \mathrm{C}$; and the final extension at $72^{\circ} \mathrm{C}$ for 5 mins. The PCR reactions were held at $4^{\circ} \mathrm{C}$ until fragment analysis was performed on an agarose gel. The amplicons from papaya and $V$. quercifolia were prepared for DNA sequence analysis using a Big Dye terminator reaction and their sequences were analysed using ABI3130 (Applied Biosystems) by the Griffith University DNA Sequencing Facility at Griffith University, Nathan, Australia.

Raw DNA sequences were analysed and trimmed at Phred quality score of 30 using 4Peaks software version 1.7.1 (4Peaks by A. Griekspoor and Tom Groothuis, mekentosj. com). The sequences were then aligned and optimized for megablast (Zhang et al., 2000) and searched for similarity to the papaya genome on NCBI database and optimised for megablast using BLASTN2.2.28+ program (Altschul et al., 1997) with E-value cut off at $1 \mathrm{E}-04$.

\section{RESULTS AND DISCUSSION}

\section{Localization of prsv-1 Locus on the Papaya Genetic Map}

The sequences of two alleles, Opa11_5r and Opk4_1r (marker named PsiIk4), which were identified as having $100 \%$ and $99 \%$ linkage to $p r s v-1$ in $V$. pubescens (Dillon et al., 2006) were used to search for sequence homology on the papaya genome database. The sequence of Opa11_5r in C. papaya '2.001', V. pubescens and V. quercifolia was linked 
to papaya uncontig 7858 at $98 \%$; and the sequence of $V$. parviflora was linked to uncontig_7858 and LG5 contig_3254, at 49\% and 32\% query cover (Table 1). The sequences of Opa11_5r on papaya uncontig_7858 and supercontig_28 (SG28) were then aligned using BLASTN to search for similarity. It revealed the three sequences have 99$100 \%$ identity and indicated this part of the genome could be located on SC28 of the papaya genome (M.R. Razean, pers. commun.) in an opposite orientation (plus to minus, Table 2).

The allele of Opk4_1r was absent in C. papaya '2.001' genome, therefore, only the sequences on three Vasconcellea species were available to search for their similarities on the papaya database. The three sequences covered $73-77 \%$ of $C$. papaya chromosome LG5 contig 3254, which is the same contig to which Opa11_5r of $V$. parviflora showed similarity (Table 1). The locus Opk4_1r of $V$. pubescens showed $85 \%$ identity to $C$. papaya chromosome LG5 contig_3254 and SC9 with 4\% gaps in the opposite orientation (plus to minus strand; Table 3).

The genetic linkage map of an interspecific cross $V$. cundinamarcensis (synonym $V$. pubescens) $\times V$. parviflora from reported Opa11_5r was co-located to prsv- 1 locus, and marker PsiIk4, which was a CAPS marker developed from the Opk4_1r sequence, was located $2 \mathrm{cM}$ away from prsv-1 locus (Fig. 1a). The evidence from this research revealed the location of Opk4_1r on LG5, SC9 which was anchored at the end of LG5 (Fig. 1b-d; Chen et al., 2007; Ming et al., 2008; Porter et al., 2009). The close link between Opa11 5r and Psilk4 of $2 \mathrm{cM}$ suggested an estimated physical distance of approximately $0.5 \mathrm{Mbp}$ from the estimation of $269.15 \mathrm{Mbp}$ of physical map to $1068.6 \mathrm{cM}$ of the genetic map (Yu et al., 2009). Both Opa11_5r and Opk4_1r were aligned to the papaya genome in the opposite orientation. This could mean that if Opk4_1r was located on SC9, Opa11_5r and prsv-1 should be located between SC9 and SC18 at the end of LG5 (Fig. 1d).

\section{The Development of DNA Markers Related to PRSV-P Resistance in $V$. quercifolia}

DNA primers were designed on known DNA sequences from SC28 on STK105 and NBS28.12, and three NBS genes at the end of LG5, NBS9.305, NBS9.308 and NBS18.235. Of 24 primer pairs, 30\% successfully amplified both $C$. papaya ' 2.001 ' and $V$. quercifolia DNAs. These amplicons were then purified and their sequences aligned using align sequence nucleotides BLAST. Partial DNA sequences of five genes in this study in C. papaya '2.001' showed $98-100 \%$ identity to DNA sequence of papaya on the database which contains the genome sequence of $C$. papaya 'SunUp', while $V$. quercifolia had 89$99 \%$ sequence homology to 'SunUp' and $82-93 \%$ homology to '2.001'. The information of partial sequences of these five genes, potentially related to PRSV-P resistance, was used to design primers to identify gene expression in each of the target genes. The sequences of candidate alleles will be further tested for their functions by quantitative real time PCR.

\section{CONCLUSIONS}

The evidence of sequence alignment between the resistant locus, prsv-1, in Vasconcellea pubescens and papaya sequence on NCBI database showed that the locus is located on supercontig 28 and could be anchored at the end of linkage group 5 of the papaya genetic map (Chen et al., 2007). DNA sequences of $V$. quercifolia and Carica papaya '2.001' showed 89 to $99 \%$ sequence identity in the region of the end of linkage group 5 . This region could be related to PRSV-P resistance in Vasconcellea spp.

\section{ACKNOWLEDGEMENTS} funds.

We thank Papaya Australia and Horticulture Australia Limited for their research

\section{Literature Cited}

Altschul, S.F., Madden, T.L., Schaffer, A.A., Zhang, J., Zhang, Z., Miller, W. and Lipman, D.J. 1997. Gapped BLAST and PSI-BLAST: a new generation of protein database search programs. Nucleic Acids Research 25:3389-402. 
Badillo, V.M. 1993. Caricaceae. Segundo Esquema. p.43. Revista de la Facultad de Agronomia de la Universidad Central, Alcance, Maracay, Venezuela.

Badillo, V.M. 2001. Nota correctiva Vasconcellea S. Hill. y no Vasconcella (Caricaceae). Ernstia. 11:75-76.

Chen, C., Yu, Q., Hou, S., Li, Y., Eustice, M., Skelton, R.L., Veatch, O., Herdes, R.E., Diebold, L., Saw, J., Feng, Y., Qian, W., Bynum, L., Wang, L., Moore, P.H., Paull, R.E., Alam, M. and Ming, R. 2007. Construction of a sequence-tagged high-density genetic map of papaya for comparative structural and evolutionary genomics in brassicales. Genetics 177:2481-2491.

Delaporta, S.J.W. and Hicks, J. 1983. A plant DNA minipreparation. version II. Plant Molecular Biology Report 1:19-21.

Dillon, S., Ramage, C., Ashmore, S. and Drew, R.A. 2006. Development of a codominant CAPS marker linked to PRSV-P resistance in highland papaya. Theoretical and Applied Genetics 113:1159-1169.

Dillon, S., Ramage, C., Drew, R. and Ashmore, S. 2005. Genetic mapping of a PRSV-P resistance gene in 'highland papaya' based on inheritance of RAF markers. Euphytica 145:11-23.

Drew, R.A., O'Brien, C. and Magdalita, P.M. 1998. Development of Carica interspecific hybrids. Acta Hortic. 461:285-292.

Drew, R.A., Siar, S.V., O'Brien, C.M. and Sajise, A.G.C. 2006. Progress in backcrossing between Carica papaya $\times$ Vasconcellea quercifolia intergeneric hybrids and C. papaya. Australian Journal of Experimental Agriculture 46:419-424.

Ming, R., Hou, S., Feng, Y., Yu, Q., Dionne-Laporte, A., Saw, J.H., Senin, P., Wang, W., Ly, B.V., Lewis, K.L.T., Salzberg, S.L., Feng, L., Jones, M.R., Skelton, R.L., Murray, J.E., Chen, C., Qian, W., Shen, J., Du, P., Eustice, M., Tong, E., Tang, H., Lyons, E., Paull, R.E., Michael, T.P., Wall, K., Rice, D.W., Albert, H., Wang, M.-L., Zhu, Y.J., Schatz, M., Nagarajan, N., Acob, R.A., Guan, P., Blas, A., Wai, C.M., Ackerman, C.M., Ren, Y., Liu, C., Wang, J., Wang, J., Na, J.-K., Shakirov, E.V., Haas, B., Thimmapuram, J., Nelson, D., Wang, X., Bowers, J.E., Gschwend, A.R., Delcher, A.L., Singh, R., Suzuki, J.Y., Tripathi, S., Neupane, K., Wei, H., Irikura, B., Paidi, M., Jiang, N., Zhang, W., Presting, G., Windsor, A., Navajas-Pérez, R., Torres, M.J., Feltus, F.A., Porter, B., Li, Y., Burroughs, A.M., Luo, M.-C., Liu, L., Christopher, D.A., Mount, S.M., Moore, P.H., Sugimura, T., Jiang, J., Schuler, M.A., Friedman, V., Mitchell-Olds, T., Shippen, D.E., dePamphilis, C.W., Palmer, J.D., Freeling, M., Paterson, A.H., Gonsalves, D., Wang, L. and Alam, M. 2008. The draft genome of the transgenic tropical fruit tree papaya (Carica papaya Linnaeus). Nature 452:991-996.

Porter, B.W., Paidi, M., Ming, R., Alam, M., Nishijima, W.T. and Zhu, Y.J. 2009. Genomewide analysis of Carica papaya reveals a small NBS resistance gene family. Molecular Genetics and Genomics 281:609-626.

Tennant, P.F., Gonsalves, C., Ling, K.S., Fitch, M.M.M., Manshardt, R.M., Slightom, J.L. and Gonsalves, D. 1994. Differential protection against Papaya Ringspot Virus isolates in coat protein gene transgenic papaya and classically cross protected papaya. Phytopathology 84(11):1359-1366.

Untergrasser, A., Cutcutache, I., Koressaar, T., Ye, J., Faircloth, B., Remm, M. and Rozen, S. 2012. Primer3 - new capabilities and interfaces. Nucleic Acids Research 40:e115.

Yu, Q., Tong, E., Skelton, R.L., Bowers, J.E., Jones, M.R., Murray, J.E., Hou, S., Guan, P., Acob, R.A., Luo, M.-C., Moore, P.H., Alam, M., Paterson, A.H. and Ming, R. 2009. A physical map of the papaya genome with integrated genetic map and genome sequence. BMC Genomics 10:371-371.

Zhang, Z., Schwartz, S., Wagner, L. and Miller, W. 2000. A greedy algorithm for aligning DNA sequences. Journal of Computational Biology 7:203-214. 


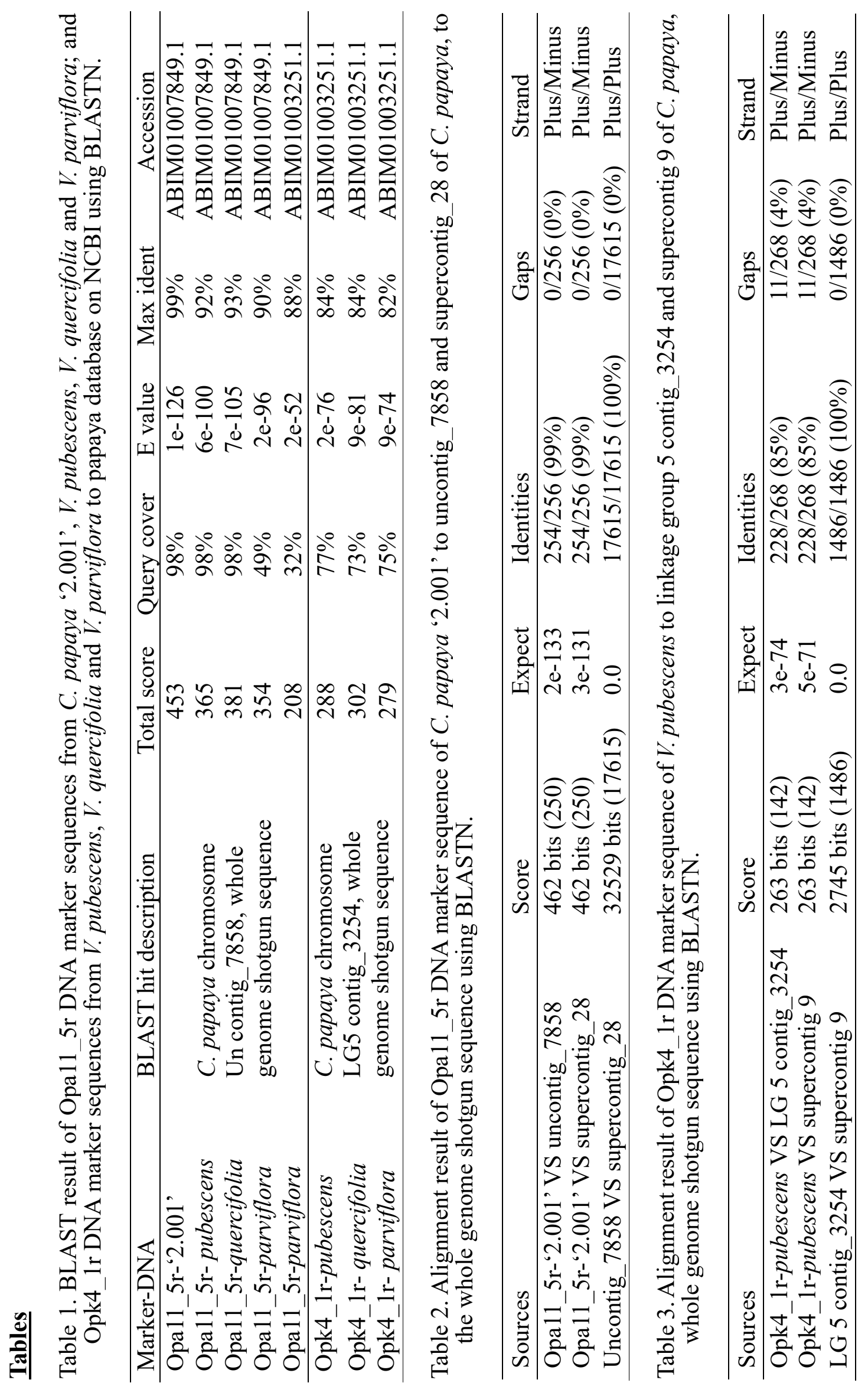



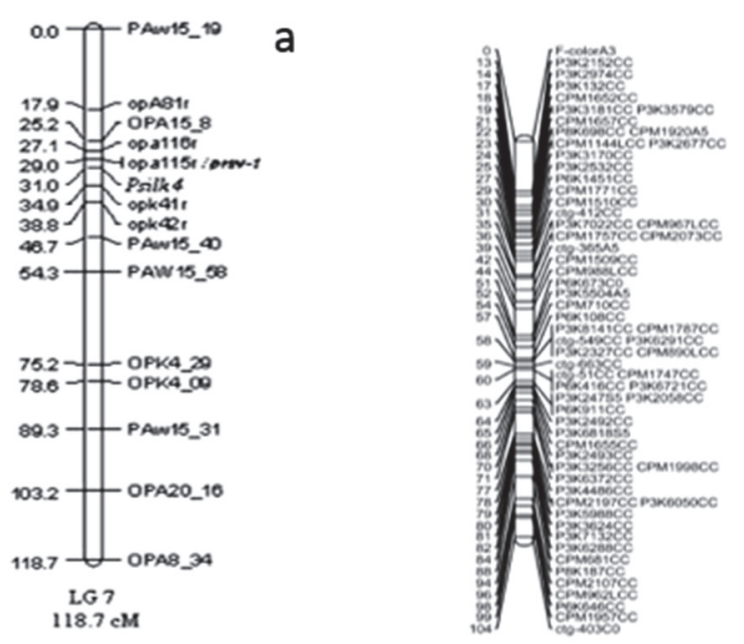

b

C

d

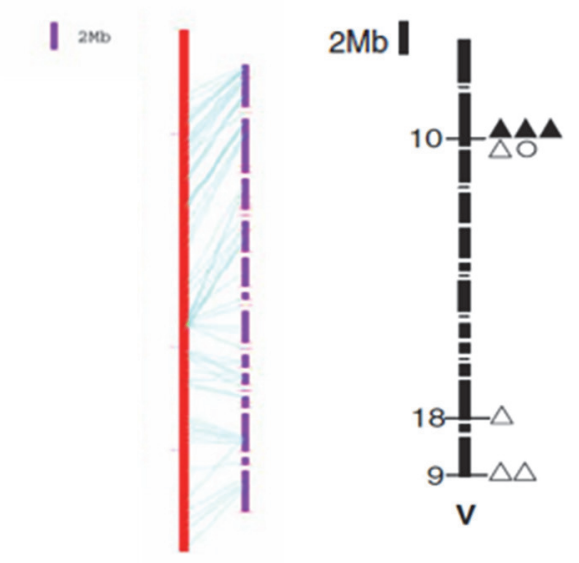

Fig. 1. a) A genetic linkage map of $V$. cundinamarcensis using RAF and CAPS markers that identified prsv-1 locus; b) SSR genetic map of C. papaya 'SunUp', linkage group 5 (Chen et al., 2007); c) Assembled papaya genome anchored to linkage group 5 (solid red bar on the left) using SSR markers (blue lines) to each scaffold [purple bars; (Ming et al., 2008)]; d) Distribution of predicted C. papaya encoding NBS genes on linkage group 5 (Porter et al., 2009). 